\title{
A novel mechanism of murine hepatocyte death inducible by Concanavalin A
}

\author{
Marcel Leist and Albrecht Wendel \\ Biochemical Pharmacology, Faculty of Biology, University of Konstanz, Germany
}

Background: Concanavalin A (Con A) is a plant lectin that polyclonally activates T-cells. When given intravenously to mice it induces a selective liver failure. Hepatotoxicity following Con A administration involves the systemic release of tumor necrosis factor.

Methods: We used primary murine hepatocyte cultures to investigate mechanisms of hepatocytotoxicity related to this animal model of inflammatory liver failure.

Results: Con A was directly toxic for cultured hepatocytes. This toxicity did not require additional cytokines or the presence of $T$ cells. Cytotoxicity due to Con $A$ involved specific binding of the lectin to mannosyl cell surface receptors, but no internalization. Other structurally similar lectins lacked such an in vitro hepatocytotoxicity. Con A induced initially reversible alterations of the morphology that were different from the ones caused by classical hepatotoxins. Con A-induced cell death was highly specific for murine hepatocytes. It was neither apoptotic by morphology nor did it involve DNA fragmentation. In addition, Con A caused a fall in cellular total glutathione content and an increase in transcriptional activity. Stabilization of microtubules by taxol completely protected cells from the lectin.

Conclusions: Stimulation of hepatocytes with Con A elicits a novel mechanism of cytotoxicity due to inappropriate excessive stimulation of membrane receptors and subsequent disturbance of the cytoskeleton.

Key words: Cytotoxicity; Glutathione; Lectin; Liver; Taxol
$\mathrm{C}^{\mathrm{o}}$ oncanavalin A (Con A) is a lectin derived from the seeds of jack beans (Canavalia ensiformis) that has been widely used as a tool in biology. It was the first lectin whose three-dimensional structure was elucidated and its physicochemical characteristics have been characterized in detail $(1,2)$. At physiological $\mathrm{pH}$ Con $\mathrm{A}$ is a non-glycosylated homotetramer that can be dissociated into stable dimers (3) or monomers (4) by succinylation or photoalkylation, re-

Abbreviations: Con A, Concanavalin A; LDH, lactate dehydrogenase; MTT, 3-(4,5-Dimethylthiazol-2-yl)-3, 5diphenytetrazolium bromide; $\alpha-\mathrm{mm}, \alpha$-methylmannopyranoside.

Received 26 July; revised 20 December 1995; accepted 29 January 1996

Correspondence: Prof. Dr. Albrecht Wendel, Biochemical Pharmacology, Faculty of Biology, University of Konstanz, POB 5560-M668, D-78434 Konstanz, Germany. Tel.: 49-7531-882113, Fax: 49-7531-993099. spectively. Each monomer contains a carbohydrate binding site with known specificity (5) and structure (6). The lectin binds most avidly to $\alpha$-D-mannopyranosyl residues. It has lower affinities for glucopyranosides, fructofuranosides or arabinofuranosides. In contrast to some bifunctional lectins, that cause some of their biological effects independently from their carbohydrate recognition domain (7), all known biological actions of Con A seem to be initiated by interactions with its sugar binding site.

Lectins occur also in mammalian organisms (8). Among these mammalian lectins lung surfactant proteins have important immunological functions and are activators of macrophages (9). In addition, the cytokine tumor necrosis factor, which is a terminal mediator of inflammatory liver damage in galactosamine-sensitized mice (10), is a mammalian lectin (11) with direct toxicity towards microorganisms (12), besides its known cytotoxicity for a variety of cell lines (13). 
The plant lectin Con A binds to surface glycoproteins and glycolipids of many cell types, e.g. leukocytes $(14,15)$, hepatocytes $(16)$ and a large number of transformed and nontransformed cell lines $(17,18)$. Moreover, it may induce a distinct metabolic response after binding to structures such as the insulin receptor on the surface of adipocytes $(19,20)$ or to molecules encoded by the major histocompatibility complex in mice (15). Mitogenic activation of T cells associated with cytokine expression and secretion is one of the best-known activities of Con A (21). Such a proliferative response is generally thought to be due to receptor cross-linking, but has also been observed with monomeric or dimeric Con A species $(3,4)$.

The toxicity of Con A has received little attention although the lectin is a powerful immunostimulant (22) and inflammogen (23) in vivo. Con A-induced cytotoxicity towards a variety of cell lines has already been described 20 years ago $(17,24)$, but since then it has never been characterized in greater detail. Intravenous administration of Con $A$ to mice leads to a fulminant organ failure of the liver only (25). Several other lectins with similar structure or sugar specificity were not hepatotoxic in this model of autoreactive liver injury although they were mitogenic for lymphocytes. The pathomechanisms induced by Con A-injection involve the activation of $\mathrm{T}$ lymphocytes and the reticuloendothelial system, which results in the systemic release of a variety of cytokines (26). Tumor necrosis factor, one of the cytokines that is secreted into the serum upon Con A-injection, was identified as the pivotal distal pathogenic mediator $(26,27)$. In this respect the pathomechanism of Con A-induced liver failure resembles various models of T-cell-induced shock elicited by polyclonal T-cell mitogens such as anti-CD3 antibodies (28) or bacterial superantigens (29), respectively. D-galactosamine that selectively inhibits hepatic transcription (30) is commonly used to sensitize mice towards these stimuli $(31,32)$. A characteristic feature of models using sensitized mice is that stimulation of the lymphoid system causes a fulminant hepatic failure, i.e. a localized single-organ failure instead of a general shock symptomatology. The time course of the damage and the cytokines mediating liver failure are similar to that observed after Con A administration $(27,32,33)$. In contrast to all other models, however, the induction of rapid and pronounced hepatic damage by Con $\mathrm{A}$ treatment did not require any sensitization of the mice and Con A itself did not influence hepatic RNA synthesis in vivo (34). It therefore seemed necessary to investigate whether and in which way Con A would directly affect murine hepa- tocytes in order to find a rationale for the hepatotropic toxicity of this lectin.

\section{Materials and Methods \\ Animals}

Male BALB/c or C57BL/6 mice (25 g, from the internal animal breeding house, University of Konstanz) were kept under controlled conditions $\left(22^{\circ} \mathrm{C}, 55 \%\right.$ humidity, $12 \mathrm{~h}$ day/night rhythm) on a standard laboratory chow (Altromin 1313). Mice lacking the gene for the $55 \mathrm{kDa}$ TNF-receptor (35) were a gift from Drs. W. Lesslauer and H. Bluethmann (F. HoffmanLaRoche, Basel). MRL/MpJ-lpr/lpr mice lacking a functional CD95 cell surface receptor ( $\cong$ fas; Apo-1) were obtained from Harlan (Austerlitz, Netherlands). Animals received humane care in adherence to the $\mathrm{NIH}$ guidelines as well as to legal requirements in Germany.

\section{Reagents}

Recombinant murine TNF- $\alpha$ was generously provided by Dr. Adolf (Bender and Co., Vienna, Austria). Monospecific ovine anti murine tumor necrosis factor- $\alpha$ immunoglobulin was prepared by S. Jilg from this laboratory (10). Unless further specified, all reagents were purchased from Sigma (Deisenhofen, Germany).

\section{Murine hepatocyte cultures}

Hepatocytes were isolated after pentobarbital anesthesia $(120 \mathrm{mg} / \mathrm{kg})$ of the mice by the two-step collagenase perfusion method of Seglen (36) as described previously $(10,27)$ with a viability exceeding $80 \%$ according to the trypan blue exclusion method and a yield of $50-60 \times 10^{6}$ cells/mouse liver. After two washes by centrifugation for $2 \mathrm{~min}$ at $50 \mathrm{~g}$, $8 \times 10^{4}$ hepatocytes in $200 \mu \mathrm{l}$ RPMI 1640 medium (Biochrom, Berlin, Germany) containing 10\% newborn calf serum (NCS) were plated in 24-well plates (Greiner, Frickenhausen, Germany). They were allowed to adhere to culture plates for $5 \mathrm{~h}$ before the medium was exchanged for RPMI medium without serum. The seeding efficiency of viable cells was $>90 \%$. Experiments were carried out at $37^{\circ} \mathrm{C}$ in an incubator gassed with $5 \% \mathrm{CO}_{2}, 40 \% \mathrm{O}_{2}$ and $55 \% \mathrm{~N}_{2}$. Hepatocyte cultures initially contained about 5\% Kupffer cells as determined by phagocytosis of fluorescein-labeled latex $(\phi 0.75 \mu \mathrm{m}$ from Polyscience Inc., Eppelheim, Germany) and esterase staining. Substances used for pharmacological or biochemical characterization of Con A-induced hepatocytotoxicity were generally added to the cultures $30 \mathrm{~min}$ before Con $\mathrm{A}$ and remained in the culture medium 
together with Con A until the experiment was terminated.

\section{Experimental conditions for cell lines and non-liver primary cells}

The HepG2 or BRL liver cell lines were kept in RPMI 1640 medium supplemented with $10 \%$ fetal calf serum. For binding experiments they were plated out at a density of $8 \times 10^{4}$ cells/well in 24-well plates (Greiner, Frickenhausen, Germany) and left to adhere overnight. Spleen cells or lymph node cells were prepared according to Kleiman et al. (37). All cell types and cell lines used for toxicity experiments were tested in parallel incubations both in RPMI medium alone or in medium containing $10 \%$ NCS for $20 \mathrm{~h}$ at the same culture conditions as described for murine hepatocytes. All experiments using cell lines were performed at least three times on different days. At the density of $8 \times 10^{4}$ cells/well none of the cell lines was confluent and cells were in the dividing phase during the experiments.

\section{Cytotoxicity and proliferation assays}

Total cellular glutathione was determined according to the enzymatic cycling method (38) after medium removal and addition of $250 \mu \mathrm{l}$ cold HCl/EDTA $(0.1$ $\mathrm{M} / 10 \mathrm{mM}$ ). LDH was determined in culture supernatants (Sup), and in the remaining cell monolayer (Cell) after lysis with $0.1 \%$ Triton X-100 (39). The percentage of LDH-release was calculated from the ratio:

$$
\frac{L D H_{S u p}}{L D H_{\text {Sup }}+L D H_{\text {Cell }}}
$$

When toxicity was to be prevented by putative inhibitors such as taxol, specific toxicity in the presence of inhibitor was defined as:

$$
100 \times \frac{\% L D H_{\text {Con A+inhibitor }}-\% L D H_{\text {basal }}}{\% L D H_{\text {Con A }}-\% L D H_{\text {basal }}}
$$

Alternatively, the capacity to produce formazan from MTT was measured essentially according to Mosmann (40). Briefly, at the end of the incubation period, cells were incubated with $0.4 \mathrm{mg} / \mathrm{ml} \mathrm{MTT} \mathrm{for}$ 30 min prior to medium removal. Reduced MTT was measured spectrophotometrically at 560/690 nm after lysis of cells (containing formazan crystals) with 200 $\mu \mathrm{i}$-propanol/formic acid (95:5) and transfer of 100 $\mu l$ of this solution to 96 -well microtiter plates. Nonhepatic cell lines were incubated for $2-4 \mathrm{~h}$ until sufficient MTT was reduced in untreated controls to yield a signal of about $800 \mathrm{mOD}$. Non-adherent cells were lysed by addition of $50 \mu \mathrm{HCl} / \mathrm{SDS}$ ( $4 \mathrm{mM} / 4 \%$ final concentration). Proliferation of lymphoid cells was determined according to Mosmann (40) after incubation for $48 \mathrm{~h}$ with various lectins. Fluorescein diacetate was used in a concentration of $1 \mu \mathrm{M}$ and incubated for $20 \mathrm{~s}$.

\section{Protein and RNA synthesis measurements}

For the determination of protein or RNA synthesis $8.4 \times 10^{4} \mathrm{~Bq}{ }^{3} \mathrm{H}$-uridine or $1.85 \times 10^{5} \mathrm{~Bq}{ }^{3} \mathrm{H}$-leucine were added to hepatocytes. After $2 \mathrm{~h}$ the medium was removed and cells were washed 3 times with ice cold $10 \%$ trichloroacetic acid. The cells were then lysed for $12 \mathrm{~h}$ at $37^{\circ} \mathrm{C}$ in $0.5 \mathrm{M} \mathrm{NaOH} / 1 \mathrm{mM}$ EDTA/0.1\% Triton X-100 and an aliquot was used for determination of acid-precipitable incorporated radioactivity.

\section{DNA-fragmentation}

After incubation with different stimuli cells were finally lysed within the culture dish with $0.1 \%$ Triton $\mathrm{X}-100$ and DNA fragmentation was determined according to McConkey et al. (41). Alternatively, DNA fragmentation was measured as described (42) by quantification of cytosolic oligonucleosomebound DNA using an ELISA-kit (Boehringer, Mannheim, Germany).

\section{Microscopy}

Light microscopic observations were performed in situ on the culture plates. Fluorescence microscopy was performed on an Axiovert 35, Carl Zeiss (Oberkochen, Germany) using hepatocytes grown on collagen-coated cover slips. They were fixed for 10 min in $3.7 \%$ formaldehyde and made permeable with $0.1 \%$ Triton X-100 for actin staining with $200 \mathrm{nM}$ fluorescein-phalloidin or made permeable with $80 \%$ methanol $\left(-20^{\circ} \mathrm{C}\right)$ for $5 \mathrm{~min}$ and postfixed with cold acetone for tubulin staining with an anti-tubulin monoclonal antibody (1:20) and a rhodamine-coupled secondary antibody (1:20). For scanning electron microscopy of hepatocytes in culture, these were grown on collagen coated round cover slips in 24well plates. After different time points medium was removed and cells were fixed with $0.7 \%$ glutaraldehyde in $50 \mathrm{mM}$ sodium cacodylate buffer and postfixed with $1 \% \mathrm{OsO}_{4}$. After dehydration and embedding (Spurr's resin) cell specimen were critical pointdried, sputtered with $5 \mathrm{~nm}$ palladium-gold and viewed in an electron microscope (model 505, Philips Electronic Instruments, Mahwah, NY, USA).

\section{Hemagglutination and cell binding}

For the determination of lectin binding, cells were fixed with formaldehyde and washed several times 
with saline containing $15 \mathrm{mM}$ phosphate, $\mathrm{pH} 7.4$ (PBS). Fixation was shown not to alter the number of binding sites in accordance with data presented by Peschke et al. (14). After incubation of the cells with solutions of fluorescein-labeled Con $\mathrm{A}$ in $\mathrm{PBS} / 2 \%$ bovine serum albumin (BSA) for $60 \mathrm{~min}$ at $37^{\circ} \mathrm{C}$, they were washed several times with cold $\mathrm{PBS} / 2 \%$ BSA and then further incubated for $90 \min \left(37^{\circ} \mathrm{C}\right)$ in a solution containing $50 \mathrm{mM} \alpha$-methylmannoside $(\alpha-$ $\mathrm{mm}), 5 \mathrm{mM}$ EDTA and 2\% BSA. An aliquot of this supernatant was diluted in $1 \mathrm{M}$ imidazole buffer $(\mathrm{pH}$ 6.8) and used for fluorescence determination on a Perkin Elmer 650-40 fluorimeter. Arbitrary fluorescence units were calibrated using different dilutions of fluorescein-labeled Con A. For toxicity experiments with different cell types fluorescence values are given per mg cellular protein (43). When binding inhibition was tested in the assay, cells were preincubated for $10 \mathrm{~min}$ with inhibitor before fluoresceinlabeled Con A was added.

For the determination of hemagglutination, washed murine red blood cells were used at a final concentration of $1.2 \%$ in saline containing $1 \mathrm{mM}$ $\mathrm{CaCl}_{2}$ and $1 \mathrm{mM} \mathrm{MnCl}$. They were mixed with serial dilutions of various lectins in V-form microtiter plates at a final volume of $120 \mu \mathrm{l}$ and agglutination was determined after $2 \mathrm{~h}$ at room temperature. For agglutination inhibition assays a fixed Con A concen-

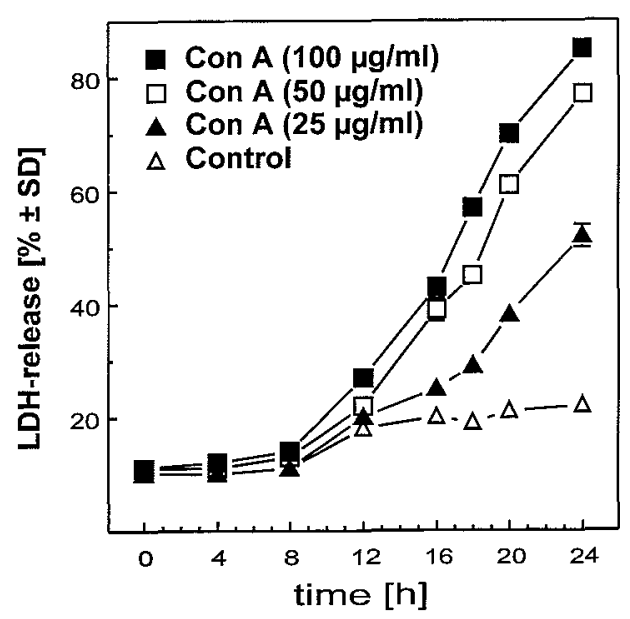

Fig. 1. Time-dependence of Con A-induced toxicity in primary mouse liver cell cultures at different concentrations of the lectin. $8 \times 10^{4}$ Hepatocytes were incubated in $200 \mu \mathrm{l}$ RPMI 1640 medium alone or medium containing Con A. The lectin was added to the incubations as stock solution in a volume of $10 \mu \mathrm{l}$. After the times indicated, viability was determined by the assessment of $L D H$-release into the medium. Data represent means $\pm S D$ from triplicate determinations.

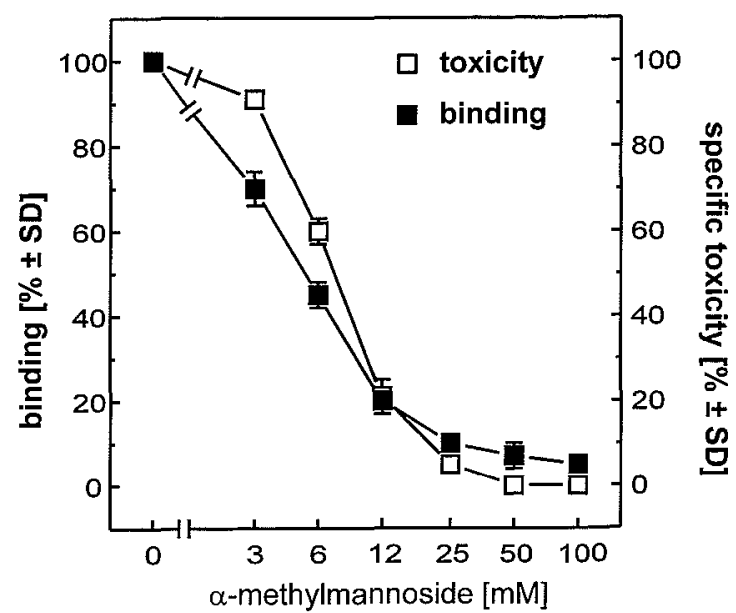

Fig. 2. Correlation of binding and toxicity induced by Con $A$ in murine liver cell cultures. For the determination of Con A-binding or Con A-toxicity, $8 \times 10^{4}$ hepatocytes (200 $\mu \mathrm{l} /$ well) were incubated with $100 \mu \mathrm{g} / \mathrm{ml}$ of the lectin in the presence of varying concentrations of $\alpha-m m$. Specific toxicity was determined after $20 \mathrm{~h}$ by assessment of $\mathrm{LDH}$-release of untreated controls, Con A-treated cells and hepatocytes treated with sugar plus lectin. Binding was determined by quantitating the fluorescence of fuoresceinlabeled Con $A$. Data represent means $\pm S D$ from triplicate determinations.

tration of $50 \mu \mathrm{g} / \mathrm{ml}$ was used together with serial dilutions of the inhibitor.

\section{Statistics}

Data are expressed as means \pm standard deviation (SD) with $n=3$. Unless otherwise indicated, individual data points in the diagrams that display no error bars represent standard deviations smaller than the size of the symbol. Statistical significance was determined with the unpaired Student's $t$-test if applicable, or with the Welch test if variances were inhomogeneous (F-test $<0.05$ ). All data from cell culture experiments are based on at least three individual cell preparations.

\section{Results}

\section{Con A-induced hepatocytotoxicity}

Since, with the dose of $20 \mathrm{mg} / \mathrm{kg}$, Con A induces a selective liver injury in mice within $8 \mathrm{~h}(25)$, we examined the toxicity of the lectin in primary murine hepatocyte cultures. As demonstrated in Fig. 1, Con A induced a concentration- and time-dependent cytotoxicity in this cell culture system. Significant LDHrelease compared to untreated control cells was detected at about $10 \mathrm{~h}$ after addition of Con $\mathrm{A}$ to the 


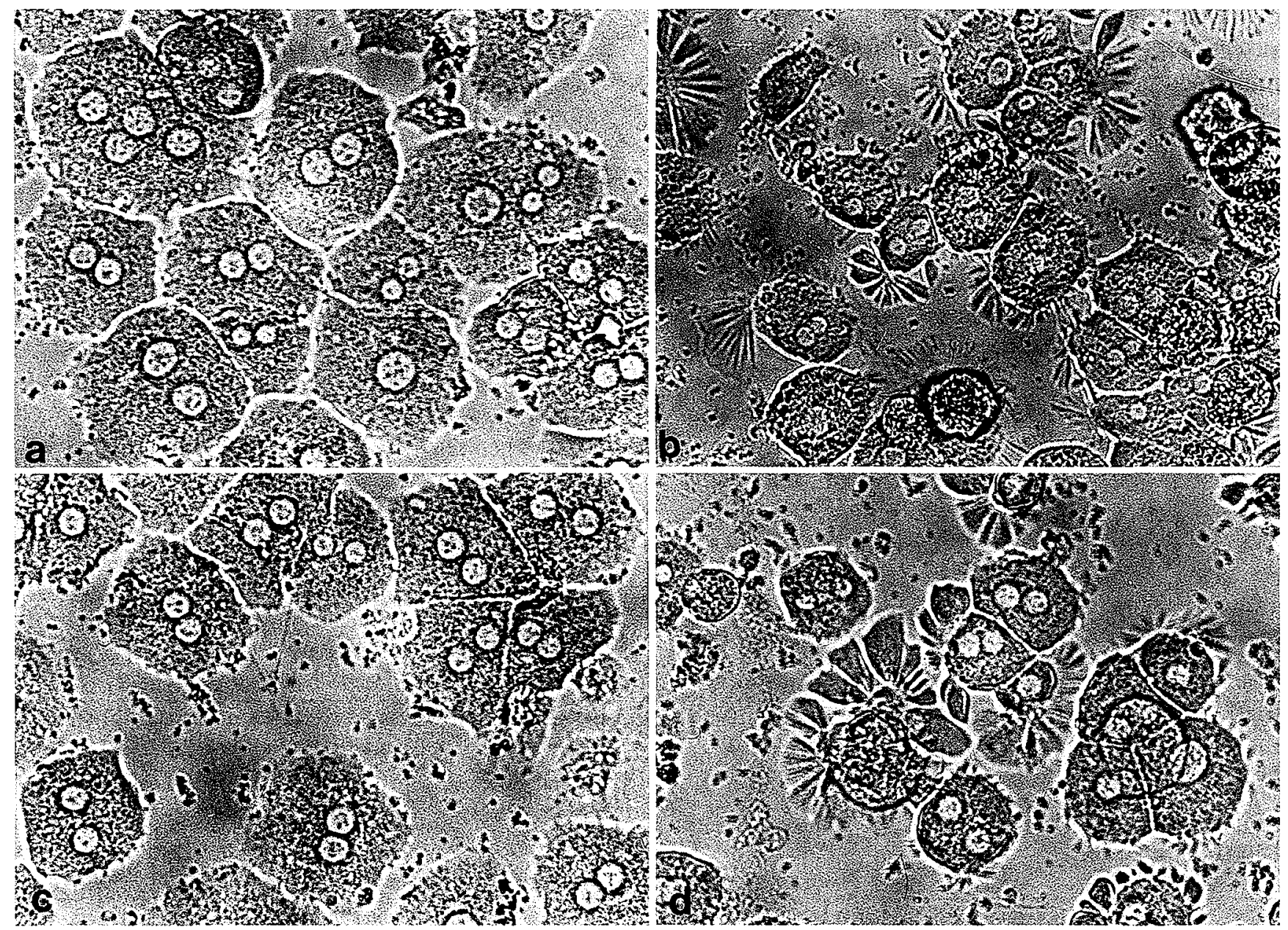

Fig. 4. Morphological alterations of cultured murine hepatocytes evoked by Con A. Five hours after seeding of freshly isolated murine liver cells in 24-well culture plates, medium was exchanged and incubations started. Untreated control cells from BALB/c wild type (A) or nude mice (D) after $3 \mathrm{~h}$. Hepatocytes treated with $100 \mu \mathrm{g} / \mathrm{ml}$ Con A (B) or with $100 \mu \mathrm{g} / \mathrm{ml}$ Con A plus $75 \mathrm{mM} \alpha-m m(C)$ for $3 \mathrm{~h}$.

\section{Evidence that internalization of Con $A$ is not required for the induction of toxicity}

For a further characterization of the hepatocytotoxicity of Con A, we checked whether internalization of the lectin was necessary. When cells were incubated with Con A bound to agarose beads, significant toxicity comparable to the one of free Con A was observed. The cytoskeletal inhibitors colchicine $(\leq 200 \mu \mathrm{M})$ or vinblastine $(\leq 1 \mathrm{mM})$, which are known to block internalization processes, did not significantly affect Con A-inducible cytotoxicity. In addition, leupeptin $(10 \mu \mathrm{M})$, chloroquine $(10 \mu \mathrm{M})$ or methylamine $(200 \mu \mathrm{M})$, which inhibit the lysosomal uncoupling of receptor and ligand, had no significant influence on Con A-induced cell damage. When cells were washed free of Con A, $4 \mathrm{~h}$ after addition of the lectin, toxicity did not occur. This demonstrates a complete reversibility of the events leading to Con Ainduced cell death within this time. Even after $6 \mathrm{~h}$ the removal of Con A from the cell surface by the addition of $75 \mathrm{mM} \alpha-\mathrm{mm}$ fully protected the hepatocytes against Con A $(22 \pm 1 \%$ LDH-release $14 \mathrm{~h}$ after the addition of the sugar ligand compared to $80 \pm 2 \%$ in cells treated with Con A only). These findings render the possibility of Con A internalization as a trigger of cytotoxicity highly unlikely.

\section{Effects of Con A on hepatocyte morphology}

When we examined the effects of Con A on the morphology of hepatocytes we detected conspicuous alterations. As early as between 2 and $4 \mathrm{~h}$ after the addition of the lectin, the cells changed their shape so that the compact cell body was surrounded with radial structures of $10-20 \mu \mathrm{m}$ length which we describe as "feathery protrusions" (Fig. 4). We examined whether these structures remained attached to the cell body and whether they were metabolically active. Using scanning electron microscopy we found 
that with all cells examined these Con A-inducible protrusions were connected to the cell body (Fig. 5), i.e. structural continuity was maintained. The fact that both MTT reduction was observed and fluorescein label was retained within these structures (data not shown) indicates that an intact cellular membrane and metabolic competence were also maintained at this stage. The Con A-inducible protrusions were reversible after addition of $\alpha$-mm up to $5 \mathrm{~h}$ after Con A challenge as determined by single cell time lapse photography. Thus, it seems that formation of the protrusions was not a final stage in the cytotoxic process, but rather an early reversible or intermediary step. Since we reasoned that cytoskeletal motility is needed for the formation of cytoplasmic protrusions and that this protrusion-forming process precedes cell death and may initiate the primary toxic reaction, we used an inhibitor of microtubule depolymerization as a tool to address this question. Taxol, a compound with this quality (45), inhibited the formation of these structures as well as cytotoxicity in a concentrationdependent fashion (Fig. 6). These findings suggest that disruptions of the cytoskeleton beyond a certain extent may allow Con A-induced cytotoxicity to proceed. Cell damage was, however, not only a simple depolymerization process of the cytoskeleton, since the inhibitor of actin polymerization phalloidin $(\leq 2 \mathrm{mM})$ or the inhibitor of tubulin polymerization vinblastine $(\leq 1 \mathrm{mM})$ neither induced morphological alterations comparable to those after treatment with Con A nor were synergistic with Con A. Moreover, staining of hepatocytes with a fluorescent phalloidin derivative or labeled tubulin antibodies revealed that microtubuli or actin filaments ran radially from the cell body to the tips of the spiky protrusions caused by Con A (data not shown). We conceive this as being consistent with restructuring, but not with total depolymerization of the cytoskeleton.

\section{Biochemical alterations in murine hepatocytes caused by Con A}

In addition to the morphological alterations, we characterized changes of some biochemical parameters induced in hepatocytes during incubation with Con A. Two hours after addition of the lectin to the culture medium, RNA-synthesis in hepatocytes was significantly increased at Con A concentrations $\geq 12 \mu \mathrm{g}$ / $\mathrm{ml}$ and reached a maximum level of $160 \pm 7 \%$ of control after the addition of $\geq 50 \mu \mathrm{g} / \mathrm{ml}$ lectin. Overall protein synthesis was not significantly different from that measured in control cells. During the incubation, the total glutathione content of hepatocytes in the presence of Con A was significantly reduced (Fig. 7), beginning as soon as $90 \mathrm{~min}$ after addition of the lectin, and this further dropped to below 20\% of controls after $9 \mathrm{~h}$. At this time, control rates of LDH-release and MTT-reduction would suggest that cellular integrity was still maintained. The threshold concentration of Con A causing such an early drop of intracellular total glutathione was $11 \mu \mathrm{g} / \mathrm{ml}$. Addition of $50 \mathrm{mM} \alpha-\mathrm{mm}$ later than $3 \mathrm{~h}$ after Con A completely reversed these changes to control levels. Repletion of intracellular glutathione with $2 \mathrm{mM} \mathrm{N}$ acetylcysteine or depletion of glutathione to $15 \%$ of controls with a combination of $250 \mu \mathrm{M}$ buthioninesulfoximine and $500 \mu \mathrm{M}$ diethylmaleate did not significantly affect the hepatocytotoxicity of Con A. Therefore, glutathione alterations seem to be a consequence or an epiphenomenon rather than a cause of Con A toxicity.
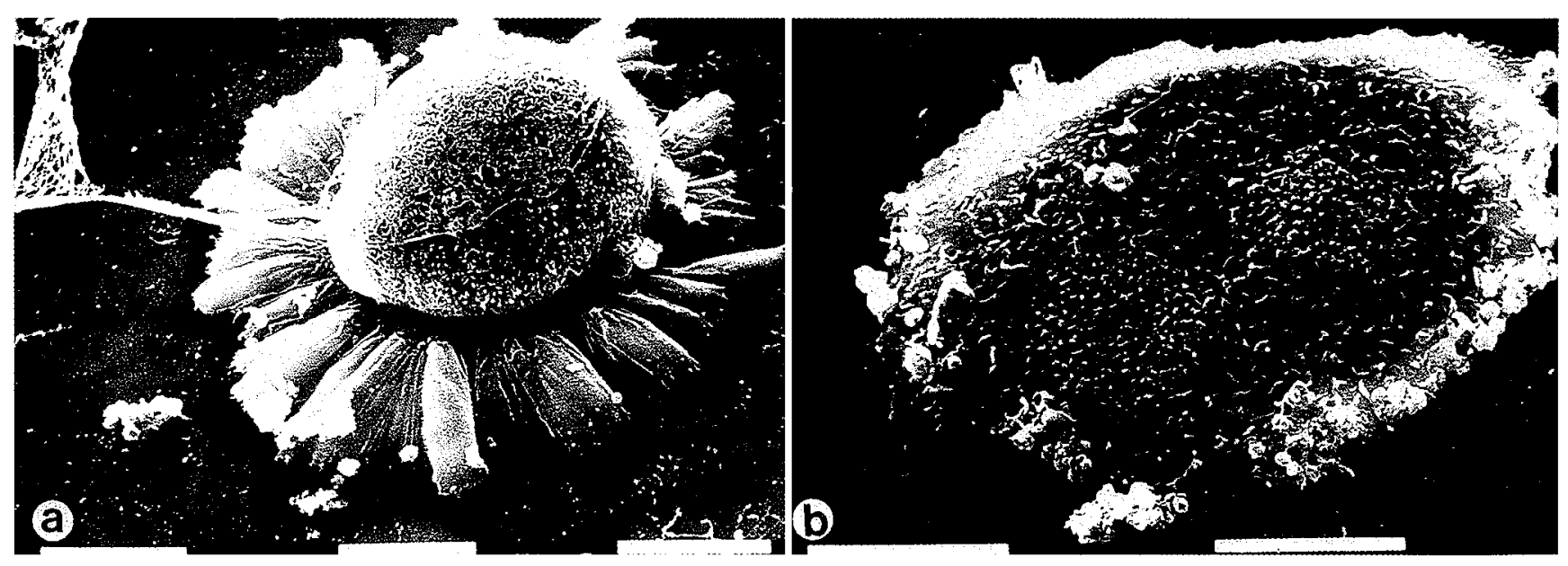

Fig. 5. Scanning electron micrographs of murine hepatocytes treated with Con A. (A) Hepatocyte 3 h after incubation with $100 \mu \mathrm{g} / \mathrm{ml}$ Con $A$. (B) Control hepatocyte displaying polygonal flat morphology. White bar: $10 \mu \mathrm{m}$. 


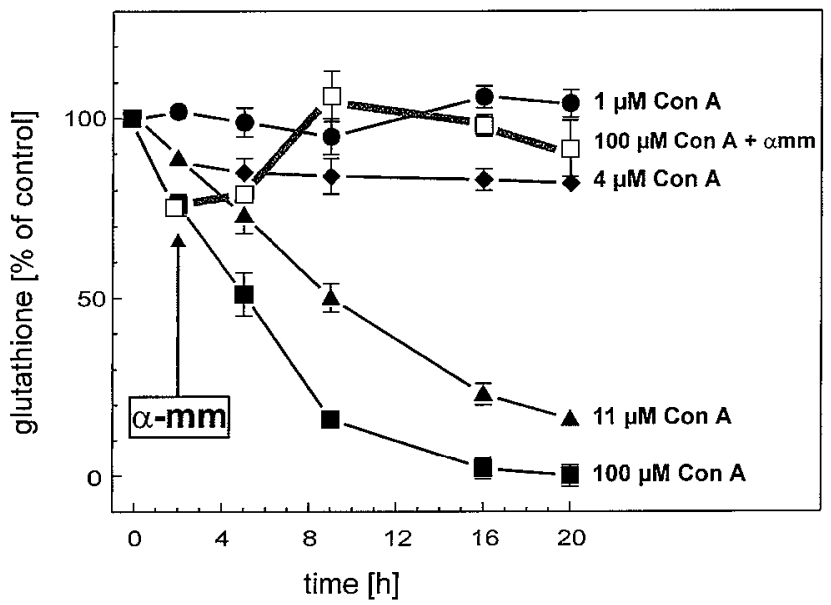

Fig. 6. Con A-induced alterations of total glutathione in murine hepatocytes. Hepatocytes were incubated with control medium or medium containing 1 (filled circles), 4 (filled diamonds), 11 (filled triangles) or 100 (filled squares) $\mu \mathrm{g} / \mathrm{ml}$ Con A. Total cellular glutathione was determined after the time periods indicated as described in Materials and Methods. $75 \mathrm{mM} \alpha$-mannoside $(\alpha-m m)$ was added after $2 h$ to an incubation containing $100 \mu M$ Con $A$ (open squares). Total glutathione content of controls was $100 \mathrm{nmol} / 106$ hepatocytes. Data represent means $\pm S D$ from three independent cell preparations.

\section{Signaling of Con A-induced hepatocytotoxicity}

First we tested whether Con A mimicked the actions of tumor necrosis factor (TNF), a hepatotoxic cytokine with lectin characteristics. Hepatocytes prepared from mice lacking the $55 \mathrm{kDa}$ TNF-receptor, which has been shown to mediate TNF-induced liver failure (10), were damaged by Con $\mathrm{A}$ to a similar extent as those derived from wild type mice (data not shown). CD95 is a cell surface receptor known to mediate hepatocyte death in vitro and in vivo (46). Involvement of this molecule is also unlikely, since hepatocytes prepared from CD95-deficient lpr-mice were also killed by Con A (data not shown). Since Con $\mathrm{A}$ is known to stimulate the insulin receptor $(19,20)$, we also checked whether an excess of this hormone may mimick or modify the toxicity of Con A. In this case, negative data did also not support this assumption.

We checked also the possibility that Con A might induce a programmed cell death, possibly via inadequate stimulation of another receptor on hepatocytes. However, we did not find a significant increase of low molecular weight DNA or of nuclear condensation with a method where a parallel experiment in actinomycin D/TNF- or anti-CD95-treated hepatocytes clearly demonstrated a large rise of these parameters $(42,46)$. These findings seem to exclude
DNA-fragmentation as a possible mechanism of Con A-induced cell death.

Since the translational or transcriptional inhibitors cycloheximide $(50 \mu \mathrm{M})$, D-galactosamine $(5 \mathrm{mM})$ or actinomycin $\mathrm{D}(333 \mathrm{nM})$ rather enhanced the damage than reduced it $\left(\mathrm{EC}_{50}\right.$ of Con A shifted from $30 \mu \mathrm{g} / \mathrm{ml}$ to $8 \mu \mathrm{g} / \mathrm{ml}$ ), we conclude that de novo synthesis of proteins is not required for Con A-induced hepatocytotoxicity.

Negative results were also obtained when we checked the role of protein kinases A or C. Neither the protein kinase A agonist dibutyryl-cyclic adenosine monophosphate $(300 \mu \mathrm{M})$ nor the adenylate cyclase stimulator forskolin $(50 \mu \mathrm{M})$, nor protein kinase C-activating phorbol esters $(1 \mu \mathrm{M})$, nor the protein kinase inhibitors $\mathrm{H}-7$ (1-(5-isoquinolinesulfonyl)-2methylpiperazine; $1 \mu \mathrm{M}$ ) or staurosporine (1 $\mu \mathrm{M})$ had any significant effect on the cytotoxicity of Con A.

In contrast to this, addition of dibutyryl-cyclic guanosine monophosphate $(300 \mu \mathrm{M})$ or addition of the cyclic guanosine monophosphate-specific phosphodiesterase inhibitor dipyridamole $(10 \mu \mathrm{M})$ reduced Con A toxicity significantly by 32 or $33 \%$, respectively.

\section{Lack of evidence for involvement of lymphocytes in}

Con A-induced hepatocytotoxicity

$\mathrm{T}$ cells are known to mediate Con A-induced liver damage in vivo (25). Since the presence of some contaminating lymphocytes cannot be excluded in our

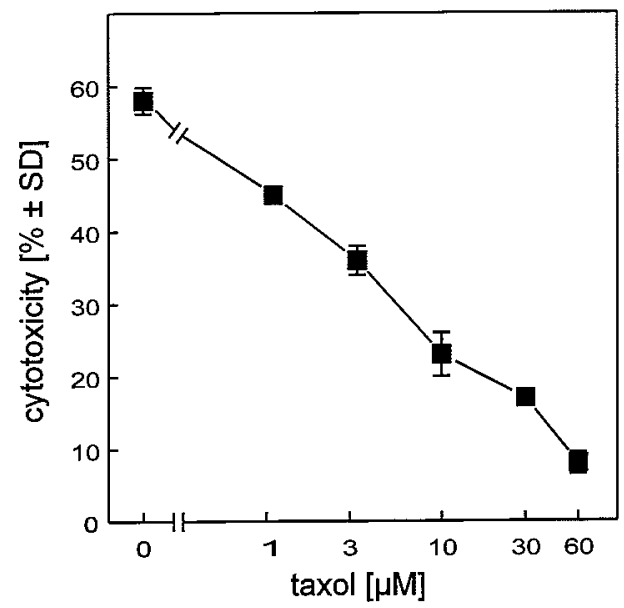

Fig. 7. Protection by taxol of murine hepatocytes against Con A-induced toxicity. Hepatocytes were preincubated for 30 min with the taxol concentrations indicated. Then incubations were continued in the presence of $50 \mu \mathrm{g} / \mathrm{ml}$ Con $A$ for $20 \mathrm{~h}$ until toxicity was determined by the MTT assay. Taxol alone was not significantly cytotoxic at the concentrations applied. Data represent means $\pm S D$ from triplicate determinations. 
primary hepatocyte cultures, we examined whether Con A toxicity towards primary murine hepatocytes was a direct effect of the lectin or possibly mediated by lymphocytes or their mediators. First of all, hepatocytes prepared from nude mice devoid of functional $\mathrm{T}$ lymphocytes did not react differently from those prepared from wild-type immunocompetent BALB/c mice. Secondly, hepatocytes prepared from mice pretreated with $500 \mu \mathrm{g} / \mathrm{kg}$ dexamethasone, a drug suppressing lymphocyte functions in vivo at this dose, were damaged by Con A to a similar extent as control cells from untreated animals. Thirdly, addition of homologous spleen cells, lymph node cells or lymphocyte cell lines to hepatocyte cultures did not significantly alter the cytotoxic response of cells towards Con A $(10-100 \mu \mathrm{g} / \mathrm{ml})$. Fourthly, the susceptibility of hepatocytes towards subsequent Con A challenge was not altered by direct addition of tumor necrosis factor $(100 \mathrm{ng} / \mathrm{ml})$, interleukin-1 $(50 \mathrm{ng} / \mathrm{ml})$, interleukin-2 $(2 \mathrm{ng} / \mathrm{ml})$ or neutralizing anti-tumor necrosis factor antibodies (shown to completely inhibit the toxicity of $100 \mathrm{ng} / \mathrm{ml}$ TNF on murine hepatocytes), or by preincubation of liver cell cultures for $24 \mathrm{~h}$ with or without Con A $(1-5 \mu \mathrm{g} / \mathrm{ml})$. Fifthly, the presence of $100 \mu \mathrm{g} / \mathrm{ml}$ Con A prevented the activation of lymphocytes as determined by IL-2 release due to its rapid cytotoxicity, whereas such concentrations of Con A killed cultured liver cells. The above findings strongly suggest that in vitro the lectin Con A kills hepatocytes directly without the involvement of lymphocytes or their cytokines.

\section{Discussion}

Like other T-cell mitogens, Con A given in vivo induces a cytokine shock syndrome. Unlike other stimulators used in murine cytokine syndrome models, it does not require a sensitization of the animals in order to induce hepatic failure. We initiated this study primarily in order to find an explanation for the specific in vivo hepatotoxicity of Con A. Since Con A inhibited transcription neither in vitro nor in vivo, a sensitization mechanism different from that of Dgalactosamine seems to exist. As demonstrated in this study, the lectin exhibited a variety of additional activities besides stimulating $\mathrm{T}$ cells. It bound directly to hepatocytes and caused a concentration and time-dependent death of murine liver cells under various culture conditions. Since we reasoned that the in vitro cytotoxicity may be an explanation for the sensitization of hepatocytes in vivo, we continued to characterize this yet unknown activity of Con A.

The strong correlation between binding of Con A to hepatocytes and its toxicity as well as the absence of evidence for lymphocyte involvement make any mechanism of toxicity other than a direct interaction of Con A with hepatocytes highly unlikely. Although lectin binding to cells was a necessary condition for the cytotoxicity of Con $\mathrm{A}$, this characteristic alone was not sufficient. This statement is based on the following three independent arguments. First, lectins other than Con A, but with similar carbohydrate specificity and affinity did not induce cytotoxicity, so that sheer protein binding to extracellular mannosylresidues may be ruled out as a mechanism initiating toxicity. Second, Con A binding and cytotoxicity on various cell types was not correlated. Thus, surface binding of Con A alone is not sufficient to account for toxicity. Third, Con A-induced cytotoxicity on murine hepatocytes was mitigated by various drugs such as phosphodiesterase inhibitors. All protective agents were also tested in the binding assay (data not shown) and were found not to interfere with lectin binding to murine hepatocytes. Thus, even when Con A bound to murine hepatocytes, its toxicity could be attenuated. Therefore biochemical events secondary to the cell membrane interaction seem to be involved in Con A-induced hepatotoxicity and not only a physical derangement of the cell surface as seen with detergent toxicity.

Some further changes in biochemical parameters were observed, such as an increase in RNA synthesis and a rapid drop of cellular total glutathione concentrations. Since data from additional experiments suggested that glutathione changes are rather an effect than a cause of Con A toxicity, we believe that cell killing by reactive oxygen species is unlikely to underlie Con A toxicity. Since the increased transcription rate provided a hint as to a possibly inadequate overstimulation of a cellular receptor, we tested some putative candidates.

As tumor necrosis factor was identified as the terminal mediator of hepatic failure in vivo following Con A injection, an obvious step was to test the involvement of the tumor necrosis factor receptor. The set of experiments we performed provides conclusive evidence that neither tumor necrosis factor receptor nor CD95 is involved in Con A toxicity. Finally, Con A has been reported to bind to murine MHC molecules and to mimick their antigenic properties (47). Since T cells were not involved in the Con A-induced toxicity observed in our culture system, it is unlikely that binding of Con A to MHC induced cell death.

The hallmark of Con A-induced hepatocyte damage in vitro was the morphological alterations of the 
hepatocytes, resulting in structures described here as "feathery protrusions". Interestingly, these structures developed within a couple of hours and were reversible to a certain extent. Although this phenomenon resembles changes of the morphology of endothelial cells exposed to Clostridium novyi $\alpha$-toxin $(48,49)$, such an observation as the consequence of a hepatotoxic reaction has to our knowledge not been described before in liver cells.

The lack of effect of cytoskeletal polymerization inhibitors and the positive staining of cytoskeletal elements suggest that Con A toxicity is not simply explained by a depolymerization process but rather involves some kind of restructuring of the cytoskeleton. This explanation is corroborated by the finding that liver cells were protected from death and from morphological alterations by pretreatment with taxol. We propose alterations in cytoskeletal membrane attachment factors as a possible, though purely conjectural, primary event of Con A-inducible cytotoxicity.

Thus, the exact mechanism of Con A-induced hepatocytotoxicity and the striking morphological alterations described in this paper remain to be elucidated. It seems that Con A induces cell death in mouse hepatocytes in a specific, direct and initially reversible way that is biochemically and morphologically different from any other hitherto described mechanism of hepatocytotoxicity. Since the pattern of toxicity of various lectins observed in vitro coincided with the pattern of hepatotoxicity in vivo, we conclude that Con A may sensitize hepatocytes directly towards further stimuli provided by polyclonal stimulation of $\mathrm{T}$ cells.

\section{Acknowledgements}

The perfect technical assistance of S. Otte is gratefully acknowledged. Special thanks go to Drs. F. Gantner and G. Tiegs for helpful discussions. Special thanks also go to Dr. H. Plattner, Konstanz, for providing the facilities for electron microscopy and to Dr. J. Hentschel for advice and practical support with the sample preparation for electron microscopy. We are indebted to Dr. E. Bade, T. Klein, U. Messmer, S. Jilg, A. Winter and D. Bundschuh for providing various cell lines or cultures and to Dr. H. Bluethmann, Hoffmann-La Roche (Basel, Switzerland) for providing TNF receptor deficient mice.

\section{References}

1. Liener IE, Isolation and properties of concanavalin A. In: Bittiger H, Schnebli HP, eds. Concanavalin A as a tool. New York: John Wiley \& Sons, 1976: 17-32.
2. Becker JW, Cunningham BA, Wang JL, Edelman GM. The molecular structure of concanavalin A. In: Bittiger $\mathrm{H}$, Schnebli HP, eds. Concanavalin A as a tool. New York: John Wiley \& Sons, 1976: 33-56.

3. Gunther GR, Wang JL, Yahara I, Cunningham BA, Edelman GM. Concanavalin A derivatives with altered biological activities. Proc Natl Acad Sci USA 1973; 70: 1012-6.

4. Griswold DE, Antell L, Bender PE, Hanna N, Poste G. Induction of suppressor cells, interleukin-2 production and mitogenesis with monomeric concanavalin A: different actions of tetrameric and monomeric concanavalin A. Mol Immunol 1985; 22: 1311-6.

5. Goldstein IJ. Carbohydrate binding specificity of concanavalin A. In: Bittiger H, Schnebli HP, eds. Concanavalin A as a tool. New York: John Wiley \& Sons, 1976: 57-68.

6. Sharon N. Lectin-carbohydrate complexes of plants and animals: an atomic view. Trends Biochem Sci 1993; 18: 221-6.

7. Barondes SH. Bifunctional properties of lectins: lectins redefined. Trends Biochem Sci 1988; 13: 480-2.

8. Drickamer K. Two distinct classes of carbohydrate-recognition domains in animal lectins. J Biol Chem 1988; 263: 9557-60.

9. Kuan SF, Persson A, Parghi D, Crouch E. Lectin-mediated interactions of surfactant protein $D$ with alveolar macrophages. Am J Respir Cell Mol Biol 1994; 10: 430-6.

10. Leist M, Gantner F, Jilg S, Wendel A. Activation of the 55 $\mathrm{kDa}$ TNF-receptor is necessary and sufficient for TNF-induced liver failure, hepatocyte apoptosis and nitrite release. J Immunol 1995; 154: 1307-16.

11. Hession C, Decker JM, Sherblom AP, Kumar S, Yue CC, Mattaliano RJ, Tizard R, et al. Uromodulin (Tamm-Horsfall Glycoprotein): A renal ligand for lymphokines. Science 1987; 237: 1479-84.

12. Lucas R, Magez S, De Leys R, Fransen L, Scheerlinck JP, Rampelberg M, Sablon E, De Baetselier P. Mapping of the lectin-like activity of tumor necrosis factor. Science 1994; 263: 814-7.

13. Goeddel DV, Aggarwal BB, Gray PW, Leung DW, Nedwin GE, Palladino MA, Patton JS, Pennica D, Shepard HM, Sugarman BJ, Wong GHW. Tumor necrosis factors: gene structure and biological activities. Cold Spring Harbor Symp Quant Biol 1986; 51: 597-609.

14. Peschke T, Wollweber L, Gabert A, Augsten K, Stracke R. Effect of different fixatives on Con A surface receptors of mouse peritoneal macrophages. Histochem 1990; 93: 4436.

15. Pink JR, Hoessli D, Tartakoff A, Hooghe R. Characterisation of Con A-binding glycoproteins from mouse splenic leukocytes by two-dimensional electrophoresis: preferential binding of incompletely glycosylated forms of $\mathrm{H}-2$ antigen to the lectin. Immunol 1983; 20: 491-7.

16. McMillan PN, Ferayorni LS, Gerhardt CO, Jauregui HO. Light and electron microscope analysis of lectin binding to adult rat liver in situ. Lab Invest 1984; 50: 408-20.

17. Ozanne O, Sambrook J. Binding of radioactively labelled concanavalin $\mathrm{A}$ and wheat germ agglutinin to normal and virus-transformed cells. Nature New Biol 1971; 232: 156-60.

18. Cline MJ, Livingston DC. Binding of 3-H-concanavalin A by normal and transformed cells. Nature New Biol 1971; 232: $155-6$.

19. Katzen HM, Vicario PP, Mumford RA, Green BG. Evidence that the insulin-like activities of concanavalin $\mathrm{A}$ and insulin 
are mediated by a common insulin receptor linked effector system. Biochemistry 1981; 20: 5800-9.

20. Shechter O. Bound lectins that mimic insulin produce persistent insulin-like activities. Endocrinology 1983; 113: 1921-6.

21. diSabato G, Hall JM, Thompson LA. T cell mitogens and polyclonal B cell activators. Meth Enzymol 1989; 150: 3-17.

22. Taniguchi K, Kawano Y, Toshitani A, Karashima A, Nomoto $\mathrm{K}$. Anti-metastatic effect by in vivo administration of concanavalin athrough augmentation of $\mathrm{T}$ derived activated killer activity: efficacy to B16 melanoma expressed MHC antigen. Cell Immunol 1989; 120: 460-9.

23. Shier WT. Concanavalin A as an inflammogen. In: Bittiger $\mathrm{H}$, Schnebli HP, eds. Concanavalin A as a tool. New York: John Wiley \& Sons, 1976; 573-80.

24. Ralph P. Differential toxicity of concanavalin A and PHA on lymphoid and hematopoietic cell lines. In: Bittiger $\mathrm{H}$, Schnebli HP, eds. Concanavalin A as a tool. New York: John Wiley \& Sons, 1976; 613-22.

25. Tiegs G, Hentschel J, Wendel A. A T cell-dependent experimental liver injury in mice inducible to concanavalin A. J Clin Invest 1992; 90: 196-203.

26. Mizuhara H, O’Neill E, Seki N, Ogawa T, Kusunoki C, Otsuka $K$, Satoh $S$, Niwa M, Senoh $H$, Fujiwara $H$. T cell activation-associated hepatic injury: mediation by tumor necrosis factors and protection by interleukin 6. J Exp Med 1994; 179: 1529-37.

27. Gantner F, Leist M, Lohse AW, Germann PG, Tiegs G. Concanavalin A-induced $\mathrm{T}$ cell-mediated hepatic injury in mice: The role of tumor necrosis factor. Hepatology 1995; 21 : $190-8$.

28. Ferran C, Sheehan K, Dy M, Schreiber R, Merite S, Landais P, Noel LH, Grau G, et al. Cytokine-related syndrome following injection of anti-CD3 monoclonal antibody: further evidence for transient in vivo T cell activation. Eur J Immunol 1990; 20: 509-15.

29. Marrack P, Blackman M, Kushnir E, Kappler J. The toxicity of staphylococcal enterotoxin B in mice is mediated by $\mathrm{T}$ cells. J Exp Med 1990; 171: 455-64.

30. Decker K, Keppler D. Galactosamine hepatitis: key role of the nucleotide deficiency period in the pathogenesis of cell injury and cell death. Rev Physiol Biochem Pharmacol 1974; 71: 77-100.

31. Miethke T, Wahl C, Heeg K, Echtenacher B, Krammer PH, Wagner $\mathrm{H}$. T cell-mediated lethal shock triggered in mice by the superantigen staphylococcal enterotoxin B: critical role of tumor necrosis factor. J Exp Med 1992; 175: 91-8.

32. Gantner F, Leist M, Jilg S, German PG, Freudenberg MA, Tiegs G. Tumor necrosis factor-induced hepatic DNA fragmentation as an early marker of T cell-dependent liver injury in mice. Gastroenterology 1995; 109: 166-76.

33. Nagaki M, Muto $Y$, Ohnishi H, Yasuda S, Sano K, Naito T, Maeda T, Yamada T, Moriwaki H. Hepatic injury and lethal shock in galactosamine-sensitized mice induced by the superantigen staphylococcal enterotoxin B. Gastroenterology 1994; 106: 450-8.
34. Leist M, Gantner F, Bohlinger I, Tiegs G, Germann PG, Wendel A. Tumor necrosis factor-induced hepatocyte apoptosis precedes liver failure in experimental murine shock models. Am J Pathol 1995; 146: 1220-34.

35. Rothe J, Lesslauer W, Lötscher H, Lang Y, Koebel P, Köntgen F, Althage A, Zinkernagel R, Steinmetz M, Bluethmann H. Mice lacking the tumour necrosis factor receptor 1 are resistant to TNF-mediated toxicity but highly susceptible to infection by listeria monocytogenes. Nature $1993 ; 364: 798-800$.

36. Seglen PO. Preparation of rat liver cells: Enzymatic requirements for tissue dispersion. Exp Cell Res 1973; 82: 391-8.

37. Kleiman NJ, Friedman DL, diSabato G. Preparation of single cell suspensions from lymphoid organs. Meth Enzymol 1984; 108: 43-9.

38. Tietze F. Enzymatic method for quantitative determination of nanogram amounts of total and oxidised glutathione: application to mammalian blood and other tissues. Anal Biochem 1969; 27: 502-22.

39. Bergmeyer HU. Methods of enzymatic analysis, 3rd edn. Weinheim, Germany: Verlag Chemie, 1984.

40. Mosmann T. Rapid colorimetric assay for cellular growth and survival: Application to proliferation and cytotoxicity assays. J Immunol Meth 1983; 65: 55-63.

41. McConkey DJ, Hartzell P, Nicotera P, Orrenius S. Calciumactivated DNA fragmentation kills immature thymocytes Faseb J 1989; 3: 1843-9.

42. Leist M, Gantner F, Bohlinger I, German PG, Tiegs G, Wendel A. Murine hepatocyte apoptosis induced in vitro and in vivo by TNF-alpha requires transcriptional arrest. $\mathrm{J}$ Immunol 1994; 153: 1778-87.

43. Bradford MM. A rapid and sensitive method for the quantitation of microgram quantities of protein utilizing the principle of protein-dye binding. Anal Biochem 1976; 72: 248-54.

44. Sigma Product Catalogue. 1994; 1799-802.

45. De Brabander M, Geuens G, Nuydens R, Willebrords R, DeMey F. Taxol induces the assembly of free microtubules in living cells and blocks the organizing capacity of the centrosomes and kinetochores. Proc Natl Acad Sci USA 1981; 78: 5608-12.

46. Leist M, Gantner F, Bohlinger I, Künstle G, Bluethmann $\mathrm{H}$, Tiegs $\mathrm{G}$, Wendel A. Fas and the $55 \mathrm{kDa}$ tumor necrosis factor receptor: two independent receptors signalling murine apoptotic hepatocyte death and liver failure. Mol Med 1995; 2: 109-24.

47. Berke G, McVey E, Hu V Clark WR. T lymphocyte-mediated cytolysis: II. Role of target cell histocompatibility antigens in recognition and lysis. J Immunol 1981; 127: 782-7.

48. Bette P, Oksche A, Mauler F, Eichel-Streiber C, Popoff MR, Habermann E. A comparative biochemical, pharmacological and immunological study of Clostridium novyi $\alpha$-toxin, $C$. difficile toxin $\mathrm{B}$ and $C$. sordellii lethal toxin. Toxicon 1991; 29: 877-87.

49. Fiorentini C, Malorni W, Paradisi S, Giuliano M, Mastrantonio P, Donelli G. Interaction of Clostridium difficile toxin A with cultured cells: cytoskeletal changes and nuclear polarization. Infect Immun 1990; 58: 2329-36. 